JAROSLAV DAVID

Jaroslav.David@osu.cz

ORCID: 0000-0003-2443-5351

University of Ostrava

Ostrava, Czech Republic

JANA DAVIDOVÁ GLOGAROVÁ

jana.davidova@osu.cz

ORCID: 0000-0002-3946-1379

University of Ostrava

Ostrava, Czech Republic
https://doi.org/10.17651/ONOMAST.65.1.15

Onomastica LXV, 2021

PL ISSN 0078-4648

\title{
PRESIDENT VÁCLAV HAVEL AS AN INSPIRATION FOR CZECH URBANONYMY*
}

Keywords: commemorative names, street names, urbanonymy, Václav Havel, Czech presidents

\section{INTRODUCTION}

The goal of the text is to focus on a specific group of commemorative place names (nazwy pamiatkowe in Polish, Ehrennamen in German), especially on street and square names, based on the personal names of Czechoslovak and Czech presidents, mostly those inspired by Václav Havel (1936-2011). Havel, the first post-Communist head of state, was President of the Czechoslovak Republic from 1989 to 1992 and held the post of President of the Czech Republic from 1993 to 2003. Although the street names including Václav Havel represent the upper, and also, the newest layer of the "presidential names" of the Czech urbanonymy in the temporal perspective, it is the opinion of the author that their research can contribute to a more detailed knowledge of the naming processes as well as of the name perception in post-totalitarian society. Thanks to the possibility of exploring various types of current-time sources - municipal agenda, scholarly reviews on the names, texts of opinion journalism, and public discussions the backstage of the process leading to the names on street signs can be revealed. The key questions we would like to answer are: What is the post-totalitarian

* The research was supported by the grant project SGS01/FF/2020-2021 Reflexe jazykové a jazykovédné problematiky v nelingvistických textech [Reflections on Language and Linguistic Issues in Non-Linguistic Texts], provided by the Faculty of Arts, University of Ostrava, Czech Republic. The authors would like to thank the reviewers for their careful reading of the manuscript and thoughtful comments aimed at improving the text.

This is an Open Access article distributed under the terms of

the Creative Commons Attribution-NoDerivatives 4.0 International (CC BY-ND 4.0) License

(https://creativecommons.org/licenses/by-nd/4.0/), which permits copying and redistribution,

commercial and non-commercial, provided that the article is properly cited.

(C) Copyright by Instytut Języka Polskiego PAN, Kraków 2021.

Publisher: Institute of Polish Language, Polish Academy of Sciences

[Wydawca: Instytut Języka Polskiego Polskiej Akademii Nauk] 
(the post-Communist, in this case) society's approach to the names commemorating the personalities connected with its establishment, in particular to Václav Havel? - Do the commemorative names bear the stigma of their participation in the creation of the memory of the totalitarian regime and its ideological world, and are they still regarded as the appropriate form of commemoration in a democratic society? - If the answer to the last question is "yes" - are their usage and perception different from the previous period, and if so, in which aspects?

\section{COMMEMORATIVE PLACE NAMES AND STREET NAMES}

In the Czech onomastic theory, the term honorifikační jméno [honorific name, name given to honour somebody/something] is used (Šrámek, 1999, p. 49; David, 2016a), despite the fact the act of its giving includes a commemorative function as well. This can be explained through the modern historical experience of the country in Central Europe, where the place names, mostly street names, were used by changing political regimes to create a new pantheon in the public space. Their instability — illustrated mostly with frequent replacements — was the reason why the names predominantly served to honour "ideologically appropriate" personalities, frequently even during their lifetimes; there was thus not any place for these names to develop their commemorative role in a longer time perspective. The fact of honorification is also reflected in the names being evaluated as expressing a false (unreal, symbolic) possessiveness (cf. Šrámek, 1999, p. 49); this semantic feature is also represented by their forms, which use language devices for the possessiveness expression: e.g., T. G. Masaryk - Masarykova Street [Masaryk's Street], or T. G. Masaryka [Street of T. G. Masaryk]. In the following text, we use the international term commemorative name.

Commemorative place names have a relatively long tradition in the region known as Czechia. From the viewpoint of the modern era, the beginning of commemoration by means of place names dates back to the 18th century (David, 2011b, pp. 23-71; David, 2016a). Over the course of the eighteenth and nineteenth centuries, it was represented mostly by the names of newly established settlements, e.g., Josefov, Františkovy Lázně, Klánovice, Terezin; they were predominantly named to honour the Habsburg emperors, and after the settlement founders and members of their families.

Spring 1848 is regarded as the starting point of the commemoration in Czech street names. At that time, Karel Havlíček Borovský, a Czech journalist and liberal politician, published the article "Všichni věrní Čechové" [All Faithful Czech People], with a proposal to rename several places in Prague to commemorate St. Wenceslaus, the patron saint of the Czech state, and the medieval king 
Charles IV, also known as the Father of the Homeland (Havlíček Borovský, 1848, p. 1). Consequently, urban names Karlova [Charles Street], Karlovo náměstí [Charles Square], and Václavské náměstí [St. Wenceslaus Square] appeared in the Prague centre, replacing the original names Jezuitská [Jesuit Street], Dobytčí trh [Cattle Market] and Koňský trh [Horse Market].

The number of names, based on the famous and ideologically preferred personalities, was essentially enriched with street and square names in the second half of the nineteenth century. The list of personalities was later complemented with namings of a group of people, names of organizations, important historical events and dates, and with geographical names.

In general, commemorative street-naming is regarded as "a dominant feature of modernity world-wide" (Azaryahu, 2020, p. 16) and "a widespread feature of modern political culture" (Azaryahu, 2009, p. 460). In terms of Czech and Central European onomastics, commemorative naming used to be connected with the totalitarian regimes of the $20^{\text {th }}$ century and mostly illustrated with place names. However, it also influenced chrematonymy, mostly the names of institutions and events - e.g., Divadlo Antonína Dvořáka [Antonín Dvořák Theatre], Základní škola Emila Zátopka [Emil Zátopek Primary School], the musical festival Smetanova Litomyšl [Smetana's Litomyšl, a town] — and personal names e.g., Soviet revolutionary names, personal names in Nazi Germany -, and has always been used in both autocratic regimes and democratic ones (cf. examples in Azaryahu, 2009, pp. 460-462).

A quick establishment process, a very tight relation to (or more precisely, dependence on) the political and social contexts, is typical of commemorative street names, along with a frequent renaming of the object (cf. David, 2011a; David, 2011b, pp. 38-58; Rose-Redwood, Kim, 2020). As concerns the persons who are chosen to be honoured and commemorated through the names in the public space, there are evident period-specific "sets" and patterns. The person in the name frequently did not have any actual relationship to the place, and the name was only used to honour and to commemorate the person in a symbolic way, to present her/his heritage and name to the public.

In current place-name research, frequently focused on street names, the concept of memory is applied, and research is focused on an interdisciplinary study of names and naming (cf. David, 2016b; Neethling, 2016; David, 2017; Kř́žová, Martínek et al., 2017; Caiazzo, Coates, Azaryahu, 2020). When used for commemorative purposes, street names become a vehicle of commemoration transposing history into the geography of the city and into the politics of public memory. As elements of language, commemorative street names introduce an authorized version of history to numerous references to - and narratives of - the 
city. "In this semiotic capacity, they introduce an official version of history into mundane settings of everyday life. [...] Their power lies in their ability to make a version of history an inseparable element of reality and it is constantly constructed, experienced, and perceived on a daily basis" (Azaryahu, 2009, pp. 460, 462; cf. Drozdzewski, 2014; Rose-Redwood, Kim, 2020). Name-giving and changes in proper names (i.e., renaming the object), revitalization (reviving the use of a name), or updating (placing a name in a new context, its transfer to another object, its usage as a metaphor, etc.) - all these activities are present in the process of commemorating important persons and in the artificial creation of their traces in the collective memory.

\section{SOURCES}

Mapping the timeline and circumstances of the insertion of Havel's name into the public space and its presentation were mostly based on archival sources collected in Knihovna Václava Havla. Dokumentační centrum [Václav Havel Library. Documentation Centre] and Czech newspapers from the period of 2011-2020 that are available online. When necessary, the source was referred to in detail. In the cases presented to illustrate the naming process, records of meetings of local authorities were used. In the case of the town of Trutnov, we drew on an e-mail interview with Zdenka Prouzová (as well as her private archive), as she is a person who actively participated in the process, and the private archive of the author, who was also involved in the matter as a specialist in onomastics.

\section{CZECHOSLOVAK AND CZECH PRESIDENTS — THE OBJECT OF CULT AND PUBLIC COMMEMORATION THROUGH PLACE NAMES}

In retrospect, the position of the presidents in Czechoslovak and Czech history is frequently characterized as a continuation of the previous monarchic tradition. The approach was adopted by the first Czechoslovak president, Tomáš Garrigue Masaryk (Kosatík, 2018, pp. 342-344; cf. Mlejnek, 2014, pp. 42-43; Pithart, 2014) and was later substantially developed by the Communist president Klement Gottwald at the turn of the 1950s (Macura, 2008, pp. 101-130). The president's residence is located at the Prague Castle, the former seat of Czech kings, with his authority, respect, and power being similar to that of a monarch. His personality is also an object of commemoration, through portraits on postage stamps and in classrooms, through sculptures situated in main squares and parks, and through place naming as well. 
As concerns the appearances of Czechoslovak and Czech presidents in place names, it is apparent that there are three different periods in the twentieth century. The first one is represented by the first Czechoslovak Republic and the postwar era, approximately until mid-1950s. This period is connected with the first Czechoslovak president Tomáš Garrigue Masaryk (1918-1935, in office), his successor Edvard Beneš (1935-1938, 1945-1948), and the first two Communist, “workers' presidents”, Klement Gottwald (1948-1953) and Antonín Zápotocký (1953-1957). Especially in cases of Masaryk and Gottwald, one can speak of a cult of personality which was officially supported and developed, even during their lives and presented by means of naming activities (cf. David, 2011b, pp. 83-87, 104-107). The name of Edvard Beneš frequently appeared immediately after the Second World War, and its usage was a mark of respect being paid to him. It also represented Czech post-war nationalism, based mostly on the anti-German atmosphere. This was the reason why Beneš's name was used for naming urban spaces in the city centers in the regions with a high density of German population and for places connected with a German presence as well as with German history and culture, cf. Adolf Hitler Platz > náměstí Presidenta Dr. Edvarda Beneše [President Dr Edvard Beneš Square] (1945, Liberec), Školní náměstí > náměstí dra Edvarda Beně̌e [Dr Edvard Beneš Square] (1945, Teplice); Schillergasse > Benešova [Beneš Street] (1945, Jihlava); Schillerovo náměstí > náměstí dr. Edvarda Beneše [Dr Edvard Beneš Square] (1945, Ostrava-Moravská Ostrava; there was also the Deutches Haus [German House] building on the premises, which was demolished after the war).

After the 1956 official Soviet criticism of the cult of Stalin, which took place during the 20th Congress of the Communist Party of the Soviet Union, commemorative activities connected with the presidents during their lives were also reduced in Czechoslovakia. Up until the end of the 1950s, it was possible to name city streets and squares after living people (cf. David, 2011b, pp. 77-80; Štěpán, 2018, pp. 86-87). There were only several restrictions, these being laws no. 266/1920 (Zákon č. 266/1920) and no. 267/1920 (Zákon č. 267/1920), which prohibited naming after people who manifested a hostile approach to the Czechoslovak Republic, or in cases where the named object did not correspond to the person's importance. In 1960, as a response to criticism of the cult of personality, law no. 36/1960 (Zákon č. 36/1960 Sb.) and the following regulation no. 97/1961 (Vyhláška č. 97/1961 Sb.) established a clear rule not to name streets after living persons. This section is also included in law no. 128/2000 (Zákon č. 128/2000 Sb.). At that time, similar laws were also passed in many countries of the Communist bloc.

From that time on, naming places after important persons was prohibited during their lifetimes - however, with certain exceptions, such as names of 
Soviet astronauts (cf. Gagarinova [Gagarin Street], 1961-1990, Kobližná Street now, Brno). Ludvík Svoboda (1968-1975) is the only Czechoslovak president after 1960 to have been commemorated in a street name; Antonín Novotný's (1957-1968) and Gustav Husák's (1975-1989) names did not appear in cities at all. Street names after Svoboda already appeared before his presidency, as he was appreciated and commemorated as the leader of the Czechoslovak troops in the Soviet Union during the Second World War (cf. streets and squares Svobodova [Svoboda Street], 1945-1951, České armády now, Litoměřice; generála Svobody [General Svoboda Street], 1945-now, Kroměřǐž; nábřeži generála Svobody [General Svoboda Waterfront], 1945-1963, Nábřeži now, Olomouc; generála Svobody [General Svoboda Street], 1945-now, Šumperk; náměstí generála Svobody [General Svoboda Square], 1945-now, Ostrava-Zábřeh; generála Svobody [General Svoboda Street], 1946-now, České Budějovice).

The rule to not name streets and squares after persons during their lifetimes is still part of Czech law and is respected in Czech naming and commemorative culture. Ivan Lutterer, a Czech linguist and onomastician, specified this in his study at the close of the Communist era in Czechoslovakia: "In the case of namings after representatives of political, economic, and partially also of scientific and cultural spheres, a sufficiently long period (20 years from their death) should be kept to prove that the person will be of importance and will be worthy of public commemoration" (Lutterer, 1988, p. 127). As will be shown below, this was only a proposal as the naming reality was different.

\subsection{Václav Havel, the first post-communist president and symbol of the velvet revolution in 1989 , and his public commemoration through place names}

Václav Havel, the president who became (along with Lech Wałęsa in Poland) a symbol of resistance to the Communist regime and the fight for freedom in Central and Eastern Europe, died on 18 December 2011. As early as 23 December 2011, the Pražský deník newspaper, along with other media, in an article Havlova ulice, náměstí i letiště [Havel Street, Square, even the Airport] listed streets and squares which "will be changed in a short time to Havel ones". Despite the enthusiasm, it also remarked: "Politicians do not agree, however, with the change everywhere" (jak (red.), 2011). To date, out of the towns listed in the article e.g., Bílina, Mikulov, Ústí nad Labem -, there is only a Václav Havel square in Hradec Králové.

Havel's death immediately initiated discussions about his commemoration and about activities aimed at introducing his name into the public space. The first recorded act of naming after Václav Havel in the Czech Republic 
was a primary school in Poděbrady, which was named Základni škola Václava Havla [Václav Havel Primary School] on 18 January 2012, a month after the former president's death. This case was not merely an empty act of naming for the sake of naming, as Havel studied in the town over the period of 1947-1950, and met there his life-long friend Miloš Forman, the film director (Forman, Novák, 1994, pp. 46-49).

There was also a huge public discussion in process. It was launched by a petition initiated by the film director Fero Fenič. Only a day after Havel's death, Fenič introduced a proposal to name the Prague airport after Václav Havel (Fenič, 2011). On 21 March 2012, the Czech government passed the new name Letišté Václava Havla Praha [Václav Havel Airport of Prague] and its English form Prague Airport - Václav Havel. However, the English name was immediately criticized by linguists as incorrect and became the subject of discussions and jokes. It was later changed to Václav Havel Airport Prague. The airport was renamed on 5 October 2012. Although the name of the airport was finally approved, there were numerous arguments against it - for example, a petition against renaming the airport emphasized the fact there was not "enough historical distance" for assessing Havel's role in history (Petice proti přejmenování, 2012). Another one focused on the named object, arguing that a university, library, theatre, etc., would possibly have been more appropriate for Havel's name (cf. another survey - Klepetko, 2014, p. 75). Nevertheless, the proposal to name the airport was inspired, by the namings of international airports, such as John F. Kennedy International Airport (New York, USA) and Aéroport de Paris-Charles-de-Gaulle (Paris, France).

Please replace the text with the following one: In December 2013, ulicka Václava Havla [Václav Havel Lane] appeared in Brno, as the third of the Havel street names in the Czech Republic, after the cities of Roztoky and Kadaň (2012; see Table 1). A small and narrow lane, situated in the city centre close to Husa na provázku theatre, was chosen at the instigation of theatre and film director Vladimír Morávek. Two public inquiries were carried out by the city hall because the first one was called into doubt. Arguments also emerged against naming such a minor object, but the proposers emphasized Havel's modesty as the main reason for choosing a lane, not a street or a square. Another argument, which appeared here and in other cases, is that there are not any addresses on the street - i.e., naming, eventually renaming, would not result in any administrative problems for city inhabitants.

On the grounds of the data collected in the RÚIAN system (Registr územní identifikace, adres a nemovitostí — the Registry of Area Identification, Addresses and Property), 8 urban areas named after Václav Havel are recorded at present 3 streets, 3 squares, and 2 waterfronts (see Table 1). 
Table — Urban places named after Václav Havel (Czech Republic, 2020)

\begin{tabular}{|c|c|c|c|}
\hline Street name & $\begin{array}{l}\text { Previous street name, if } \\
\text { replaced }\end{array}$ & $\begin{array}{l}\text { Establishment } \\
\text { (year) }\end{array}$ & City \\
\hline Václava Havla & $\begin{array}{l}\text { Fučikova (after a Communist } \\
\text { journalist Julius Fučík, a mem- } \\
\text { ber of the anti-Nazi resistance) }\end{array}$ & 2012 & Kadaň \\
\hline Václava Havla & $\begin{array}{l}\text { Kuželova (after a local mayor } \\
\text { Bohumil Kužel; after renaming } \\
\text { the street, the replaced name } \\
\text { was used to name a new street) }\end{array}$ & 2012 & Roztoky \\
\hline Václava Havla & a newly named place & 2013 & Brno \\
\hline \multicolumn{4}{|l|}{ Square name } \\
\hline náměstí Václava Havla & a newly named place & 2016 & Praha \\
\hline námèstí Václava Havla & a newly named place & 2019 & $\begin{array}{l}\text { Hradec } \\
\text { Králové }\end{array}$ \\
\hline náměstí Václava Havla & a newly named place & 2019 & Litomyšl \\
\hline \multicolumn{4}{|l|}{ Waterfront name } \\
\hline nábřeži Václava Havla & Revoluční [Revolution Street] & 2016 & Trutnov \\
\hline nábřeži Václava Havla & $\begin{array}{l}\text { a part of Labská [the River of } \\
\text { Labe Street] }\end{array}$ & 2020 & Pardubice \\
\hline
\end{tabular}

The background of the namings reflects a period which differed from the previous totalitarian one. Prior to 1990 , mostly at the first half of the 1950s, President Klement Gottwald's name was used for naming the most prestigious streets and squares in the city centre - in addition to other objects —, regardless of the administrative problems connected with changes of addresses, etc. This became the most important argument as concerns namings after Václav Havel. It was frequently emphasized that there were not or only several addresses located at the chosen urban place. It is a distinct shift from the state power arrogance of the Communist era to the current respect for people living in the named area.

However, this post-1989 approach may also have its drawbacks as the renamed objects may not match the importance of people of the status of Havel. The correspondence between the significance assigned to the historical figure and the spatial status of its commemoration, this being the basic feature of commemorative street names (cf. Azaryahu, 2009, p. 463; David, 2011b, pp. 155-157, 168), has been broken. Another feature of Havel namings is that they were mostly given to places that previously had not borne any name. Comparing this with the 1950s naming practice, the that-time strategy was completely different. The Communist 
regime wanted to erase the names of 'unsuitable' persons from the city history and memory by replacing them with ideologically 'suitable' ones. This aim is absent when giving names to streets and squares at present. This is illustrated with the Havel street name in Roztoky, where a replaced name was used for naming another street, and in both cases, there places without any addresses were chosen (Kronika města Roztoky, 2012, p. 5; see table). The last specific feature of Havel namings is that they do not represent state or local authorities-driven acts, but are based on the activities of civil society.

The scale of urban objects named after Václav Havel goes beyond the namings of streets and squares. There are more than twenty Lavička Václava Havla [Václav Havel Bench] — a set of two chairs and a round table with a lime tree situated in its centre, which symbolizes a dialogue; there are parks bearing his name, e.g., in Litoměřice and Říčany; there is Lavička Ferdinanda Vaňka [Ferdinand Vaněk Bench] in front of the Ostrava-Heřmanice prison, where Havel was imprisoned at the turn of the 1980s. Ferdinand Vaněk is Havel's alter ego in his plays.

In 2012, Olgy Havlové Street, commemorating Havel's wife Olga Havlová (1933-1996), who was greatly involved in charity work, appeared in Prague, in the Žižkov district, where she was born and spent her childhood. The only Havlová Street in the Czech Republic was not the first name given to commemorate Václav Havel's wife. Immediately after she died in 1996, a grammar school in Ostrava was permitted by Václav Havel to bear the name Gymnázium Olgy Havlové [Olga Havlová Grammar School].

However, Havel's name also appears in namings abroad. Apart from the naming of the new building of the European Parliament in Strasbourg (France, 2017), Havel Square in Haifa, a street in Jerusalem (Israel, 2015), and a boulevard in Kiev (Ukraine, 2016), Serbia holds the first place, and Poland set the world record in terms of speed. In Serbia in 2005, a street in the small village of Tcheshko Selo (Чешко Село), inhabited by Czech people, was named after Václav Havel. As early as 22 December 2011, the municipal authority of the city of Gdańsk, the home of the anti-Communist movement Solidarity (Solidarność), named a newly built avenue Aleja Vaclava Havla [Václav Havel Avenue]. In its justification, Havel's life and activities are mentioned, altogether, with the fact that the naming of the avenue does not involve any extra expenses: "Żaden z mieszkańców Gdańska nie jest zameldowany przy tej ulicy, nie działa tam też żaden z podmiotów gospodarczych, nie będzie więc konieczności wymiany pieczątek, dokumentów czy druków. [None of the citizens and economic subjects of Gdańsk are registered on the street, there is no need to exchange stamps, documents and forms]". Today, Poland has the highest number of Havel namings in the world, Czechia excluded -3 streets, 1 square and 2 roundabouts. 


\subsection{Václav Havel in the town of Trutnov - a case study}

The next part of the text will focus on a particular case — the naming of part of the waterfront in the town of Trutnov. Although Prague is the city where Václav Havel was born and spent his life (cf. Lukeš, 2018), the town of Trutnov and the region of eastern Bohemia are also closely connected with Havel's life. There are four aspects linking him to the region. First, it is the town, in particular the town brewery, where Havel had to work as an unskilled labourer for eight months in 1974. This period of his life inspired his most famous one-act play, Audience [Audience], written in 1975 (Kaiser, 2009, pp. 92-96; Žantovský, 2014, pp. 148-154). He also visited the town post office in Trutnov to transmit his texts via phone calls to Western radio broadcast stations: Radio Free Europe / Radio Liberty and Voice of America. Second, it is the locality of Hrádeček, situated $7 \mathrm{~km}$ north-west of the city centre. At the end of the 1960s, Václav Havel bought a cottage there, where he spent a number of years, organizing various underground activities, e.g., theatre performances, concerts and meetings of opponents to Communism. Third, it is the village of Bojiště, $1.5 \mathrm{~km}$ south of Trutnov town centre, where the area $\mathrm{Na}$ Bojišti is situated. The place is well-known for the open-air festival also known as český Woodstock [Czech Woodstock], organized by Havel's friends between 1987 and 2016 and commemorating his life and work; in 2012, the festival was dedicated especially to Václav Havel. The fourth, but not an unimportant point is the fact that Havel was given honorary citizenship of the town of Trutnov in 2010.

In 2016, on the fifth anniversary of Havel's death, a citizens' initiative in Trutnov proposed naming part of Horská Street in the town centre after Václav Havel; the street is situated close to areas connected with Havel's time in Trutnov: the brewery and the post office building. Although the proposal was supported by the reviews of three onomasticians, Jaroslav David (University of Ostrava, Ostrava), Václav Ledvinka (Archive of the Capital of Prague), and Pavel Štěpán (Institute of the Czech Language, Academy of Sciences of the Czech Republic, Prague), it was ultimately not accepted. The reasons were complicated by the personal relationships between members of the initiative and the municipal authority of the time, and the unprofessional presentation of the arguments (the author's personal experience and the personal testimony of Zdenka Prouzová). The authority suggested using the name for a newly established street in the town periphery, or renaming Revolučni Street, not such an impressive street at the edge of the town centre, without any direct connection to Václav Havel. After an intensive public campaign on both sides, the town authority decided to give Revolučni Street the new name nábřeži Václava Havla [Václav Havel Waterfront] in December 2016. The head of the town naming board, Vladimír Wolf, a historian, declared that the 
authors of the reviews, linguists and onomasticians, did not have enough information concerning the issue. The key argument of the town authority was that Revolučni street was not densely populated and that there were not many companies situated there (Trutnov-zápis, 2016). By only one vote, the original proposal was finally rejected, and Havel's name replaced the one of Revolučni Street.

The same argument, accompanied by aversion to another renaming, also won out in the city of Hradec Králové in June 2012, where the proposal to rename náměstí Svobody with Havel's name appeared, but was rejected (Hradec Královézápis, 2012).

\subsection{Václav Havel as a Proposer of Urban Name Change}

In the paper, attention is paid to the street names inspired by Václav Havel but the former president took an active part in the renaming of urban objects himself. The first time was in the spring of 1990, when he supported the renaming of the Prague waterfront where his flat was situated. Nábřeži Bedřicha Engelse [Friedrich Engels Waterfront] was created in 1951 by joining two originally separated waterfronts — Palackého [Palacký Waterfront] and Rašínovo nábřeží [Rašín Waterfront] (Lašt'ovka — Ledvinka, 1998, pp. 141-143). In a meeting on 29 April 1990, Havel delivered a short speech at which he explained the act of renaming: "I as a citizen am not indifferent to whether I live on a waterfront dedicated to a relatively unimportant philosopher of the last century Friedrich Engels, or on one dedicated to Alois Rašín, a man who contributed to the foundation of the country along with Tomáš Garrigue Masaryk, Milan Rastislav Štefánik, Edvard Beneš and Karel Kramár. I care about it, I confess it. The citizens of Zlín also care about whether they live in the city of Zlín, or in the city of Gottwaldov. ${ }^{1}$ And I think it is right that they care. This is probably the first reason for our meeting" (Havel, 1990).

Václav Havel actively participated in the naming process for the second time in 1994. During his meeting with Czech compatriots living in Chicago, he announced that he had proposed to the Prague municipality to name a street after Antonín Čermák [Anton J. Cermak], a Chicago mayor in the first third of the twentieth century (Havel, 1994). The street appeared on the map in the same year, when the original U hřbitova [At Cemetery Street] — situated in the district of Prague-Bubeneč — was replaced by Antonína Čermáka [Antonín Čermák Street] (Laštovka, Ledvinka, 1997, p. 48).

${ }^{1}$ In the period of 1949-1989, the city of Zlín bore the name Gottwaldov, which was inspired by the surname of the Communist president Klement Gottwald. 
These two examples illustrate Havel's open and positive approach to commemorative naming. He regarded it as part of identity creation and a form of commemoration. We have not, however, as yet determined his approach to the usage of his own name - he would have probably rejected the honour of being commemorated through his name in the public space, or would have been modestly proud of it, if it is possible to speculate about it at all.

\section{CONCLUSIONS}

At the beginning of the study, three questions were asked: What is the post-totalitarian (the post-Communist, in this case) society's approach to the names commemorating the personalities, in particular to Václav Havel? - Are the commemorative names still regarded as an appropriate form of commemoration? - And the third one: Are their usage and perception different from the previous period, and if so, in which aspects? - We summarize the answers in the following paragraphs.

The politicians' approaches, as well as public discussions, have shown that Czech society is not fully identified with the perception of Václav Havel as one of the greatest Czechs of modern history — despite the fact that he reached third place, following the medieval king Charles IV and the first President Tomáš Garrigue Masaryk, in the 2005 public-survey show Největši Čech [The Greatest Czech].

This controversy is one of the examples that lead (apart from a general aversion to naming after personalities, mostly politicians, due to the negative experience of the twentieth century and multiple renamings) to an ambiguous approach to commemorative street names. On the one hand, it is evident that Czech society maintains this commemorating practice, i.e., using honorific street names, of previous decades and centuries. On the other hand, the process of naming has turned out to be to a more public matter and has begun to respect public opinion and interests - cf. public inquiries and open discussions, efforts to minimize administrative problems for inhabitants, etc. The most visible expression of the ambiguous approach to commemorative names is that any free space in the city centre is considered an appropriate one to be named after the commemorated figure, regardless of the correspondence between his/her historical role and the named place.

In conclusion, to illustrate the ambiguous approach of the Czech people to Václav Havel and to commemoration through naming places, a section from the blog of Václav Klaus is provided here. Klaus, the prime minister and later president (2003-2013), presented himself as the main political opponent of Havel's. In the following text, he sarcastically commented on the new name of Prague airport: "I moved from Prague-Ruzyně airport to the Roma-Fiumicino airport; actually, I am thinking about it in such an old-fashioned way. However, as a matter of fact, 
I flew from Václav Havel Airport to Aeroporto Leonardo da Vinci. Renaming the Rome airport after a legend, proven by centuries, makes sense (although I do not why it happened). Renaming Ruzyně airport, however, was a spiteful act with a very short-time, i.e., non-hundred-years touch. We are always more stupid than the rest of the world and more hateful towards each other" (Klaus, 2016).

The aim of the research was to map a particular issue in the field of commemoration, this being the process of naming urban objects after President Václav Havel. Another step in the research will be to explore the archival sources collected in Archiv Kanceláře prezidenta republiky [Archive of the President's Office] in Prague. Its rich archival material, which could not be examined in 2020 due to the COVID-19 restrictions, may reveal additional aspects and developments of naming after Czechoslovak and Czech presidents and contribute to the description of varied commemorative activities and their changes within various political regimes in the twentieth century.

\section{REFERENCES}

Archiv Kanceláře prezidenta republiky [The Archive of the Republic's Presidential Office]. https://www.prazskyhradarchiv.cz/cs/archivkpr).

Azaryahu, M. (2009). Street names and iconography. In R. Kitchin, \& N. Thrift (Eds.), International Encyclopedia of Human Geography (pp. 460-465). Amsterdam: Elsevier Science.

Azaryahu, M. (2020). Name-making as place-making. In L. Caiazzo, R. Coates, \& M. Azaryahu (Eds.), Naming, Identity and Tourism (pp. 11-27). Newcastle upon Tyne: Cambridge Scholars Publishing.

Caiazzo, L., Coates, R., \& Azaryahu, M. (Eds.). (2020). Naming, Identity and Tourism. Newcastle upon Tyne: Cambridge Scholars.

David, J. (2011a). Commemorative place names — their specificity and problems. Names, 59(4), 214-228.

David, J. (2011b). Smrdov, Brežněves a Rychlonožkova ulice. Kapitoly z moderní české toponymie [Smrdov, Brežněves and Rychlonožkova Street. Chapters from Modern Czech Toponymy]. Praha: Academia.

David, J. (2016a). Honorifikační toponymum [Commemorative place name]. In P. Karlík, M. Nekula, \& J. Pleskalová (Eds.), Nový encyklopedický slovník češtiny [New Encyclopaedia of the Czech Language] (pp. 640-641). Praha: Nakladatelství Lidové noviny.

David, J. (2016b). Toponymie městského prostoru v kontextu mezioborovosti české onomastiky — kritické poznámky a perspektiva dalšího výzkumu [Toponymy of the urban area in the context of interdisciplinary approaches to Czech onomastic research — critical remarks and perspectives of further research]. Studie z aplikované lingvistiky, 7, 39-54.

David, J. (Ed.). (2017). Toponyma. Kulturni dédictví a pamět mist [Place Names. Cultural Heritage and The Memory of Places]. Ostrava: Filozofická fakulta OU.

Drozdzewski, D. (2014). Using history in the streetscape to affirm geopolitics of memory. Political Geography, 42, 66-78.

Fenič, F. (2011, December 19). Letiště Václava Havla [Václav Havel Airport]. Lidovky.cz. https://www.lidovky.cz/domov/letiste-vaclava-havla.A111219_161526_ln_redakce_mev 
Flodrová, M. (2019). Ulička Václava Havla [Václav Havel Lane]. In I. Loskotová et al., Internetová encyklopedie dějin Brna [The Internet Encyclopaedia of the History of Brno]. https://encyklopedie.brna.cz/home-mmb/?acc=profil_ulice\&load=7914

Forman, M., \& Novák, J. (1994). Co já vím? Autobiografie Miloše Formana [What do I know? An autobiography of Miloš Forman]. Brno: Atlantis.

Have1, V. (1990, April 29). Přejmenování Engelsova nábřeží na Rašínovo — projev 29. 4. 1990 [The Renaming of Friedrich Engels Waterfront to Rašínovo — Speech, 29 April 1990]. https://archive.vaclavhavel-library.org/Archive/Detail/54080/

Havel, V. (1994, October 28). Beseda prezidenta republiky Václava Havla na setkání s krajany Chicago, USA, 28. října, 1994 [Discussion of Václav Havel, President of the Republic, During a Meeting with Compatriots — Chicago, USA, 28 October 1994]. https://archive.vaclavhavel-library.org/Archive/Detail/17233/

Havlíček Borovský, K. (1848, March 19). Všichni věrní Čechové [All faithful Czech people]. Pražské noviny, 23, 1.

Hradec Králové-zápis (2016, June 26). Zápis z 19. zasedáni zastupitelstva města Hradec Králové ze dne 26. června 2016 [The Report of the 19 Meeting of the City Representatives' Board, 26 June 2012]. http://web2.mmhk.cz/zm/2012/19/

jak, red. (2011, December 23). Havlova ulice, náměstí i letiště [Havel Street, Square, and the Airport]. Pražský denik, 299, 14. https://archive.vaclavhavel-library.org/Archive/Detail/17975/

Kaczorowski, M., \& Naliwajek, J. (2012, December). Wniosek do Rady Miasta Gdańska o nadanie drodze nazwy „Aleja Vaclava Havla” [Application to the Gdańsk City Council to name a road "Vaclav Havel Avenue"]. https://s-trojmiasto.pl/download/1/wniosek_Havel_1_.pdf

Kaiser, D. (2009). Disident. Václav Havel 1936-1989 [A Dissident. Václav Havel 1936-1989]. Praha — Litomyšl: Paseka.

Kellner, P. (2012). Petice proti přejmenování letiště Ruzyně na letiště V. Havla [The Petition against the Renaming of the Ruzyně Airport to V. Havel Airport]. https://www.petice.com/proti_prejmenovani_letiste_ruzyne_na_letiste_v_havla

Klaus, V. (2016, March 23). Zápisky z cesty do jižního Maroka na Crans-Montana Forum [Notes from a Trip to Southern Morocco to the Crans-Montana Forum]. https://www.klaus.cz/clanky/3892/

Klepetko, R. (2014). Současná role národní identity aneb proč (ne)stavíme památníky [The current role of national identity or why we (do not) build monuments]. Kulturni studia, 2 (1), 64-79.

Knihovna Václava Havla. Dokumentační centrum [Václav Havel Library. Documentation Centre]. https://www.vaclavhavel.cz/

Kosatík, P. (2018). Jiný T. G. M. [A Different T. G. M.]. Praha: Nakladatelství Paseka.

Kř́ižová, L., \& Martínek, J. et al. (2017). Od Karlova mostu ke Gottwaldovu. Osobnosti v názvech měst a mist [From the Charles Bridge to the City of Gottwaldov. Personalities in the Names of Cities and Places]. Praha: Historický ústav AV ČR, v. v. i.

Lašt'ovka, M., \& Ledvinka, V. (1997-1998). Pražský uličník. Encyklopedie názvů pražských veřejných prostranství [Uličník of Prague. The Encyclopedia of Naming of Public Spaces in Prague] (Vols. 1-2). Praha: Libri.

Lukeš, Z. (2018). Václav Havel's Prague: A Guide to Buildings and Places with a Role in the Life of the Playwright, Dissident and President. Praha: Knihovna Václava Havla, o. p. s.

Lutterer, I. (1988). Názvy pražských ulic z hlediska praxe [Prague street names in a practical perspective]. In P. Žigo (Ed.), Urbanonymia. 8. - 10. októbra 1986, Modra-Piesky, zborník prednášok z 2. celoštátneho onomastického seminára [Urbanonymy. 8-10 October, 1986, Modra-Piesky. The Proceedings of the Second Statewide Onomastic Seminar] (pp. 125-128). Bratislava: Univerzita Komenského.

Macura, V. (2008). Štastný věk (a jiné studie o socialistické kultuře) [Happy Age (and Other Studies on Socialist Culture)]. Praha: Academia. 
Mlejnek, J. (2014). Prezidenti a magie charizmatického panství [Presidents and the magic of a charismatic rule]. In M. Kubát, \& T. Lebeda (Eds.), O komparativní politologii a současné české politice. Miroslavu Novákovi k 60. narozeninám [On Comparative Political Science and Current Czech Politics. Dedicated to the $60^{\text {th }}$ Birthday of Miroslav Novák] (pp. 37-43). Praha: Karolinum. Neethling, B. (2016). Street names. A changing urban landscape. In C. Hough (Ed.), The Oxford Handbook of Names and Naming (pp. 144-157). Oxford: Oxford University Press.

Pithart, P. (2014). Úvaha o prezidentech na hradě českých králů. Dvě dispozice: k pasivitě v podhradí a k vůdcovství na Hradě [An essay on presidents at the castle of the Czech kings. Two issues: passivity beneath the castle, and leadership at the castle]. Politologická revue, 20(2), 5-18.

Rose-Redwood, R., \& Kim, S. (2020). Street naming and power. In A. Kobayashi (Ed.), International Encyclopedia of Human Geography $\left(2^{\text {nd }}\right.$ Edition) (pp. 55-60). Amsterdam: Elsevier.

Štěpán, P. (2018). Namegiving in the Czech Republic: legal regulation and the role of onomasticians. Onomastica Uralica, 14, 83-92.

Šrámek, R. (1999). Úvod do obecné onomastiky [Introduction to General Onomastics]. Brno: Masarykova univerzita.

Trutnov-zápis (2016, December 12). Zápis z 5. zasedání zastupitelstva města Trutnov ze dne 12. prosince 2016 [Report of the Fifth Meeting of the City Representatives' Board, 12 December 2016]. https://materialy.trutnov.cz/file/12348/

Vyhláška č. 97/1961 Sb., o názvech obcí, označováni ulic a čislování domů [Regulation no. 97/1961, on Namings of Municipalities, Street Signs and House Numbers]. https://www.zakonyprolidi.cz/cs/1961-97

Weberová, J. (2012). Kronika města Roztoky: rok 2012 [The Chronicle of the City of Roztoky 2012]. https://www.roztoky.cz/userfiles/file/authority/kronika-mesta-roztoky-2012-1.pdf

Zákon č. 266/1920 Sb., o názvech měst, obcí, osad a ulic [Act no. 266/1920, On the Naming of Cities, Municipalities, Settlements and Streets]. https://www.beck-online.cz/bo/chapterview-document. seam?documentId=onrf6mjzgiyf6mrwgywtg

Zákon č. 267/1920 Sb., o odstranění nevhodných názvů [Act no. 267/1920, On Removal of Inappropriate Namings]. http://www.beck-online.cz/bo/chapterview-document.seam?docum entId=onrf6mjzgiyf6mrwg 4 wta

Zákon č. 36/1960 Sb., o územním členění státu [Act no. 36/1990, On the Territorial Division of the State]. https://www.zakonyprolidi.cz/cs/1960-36

Zákon č. 128/2000 Sb., o obcích (obecní zřízení) [Act no. 128/2000, On Municipalities]. https://www. zakonyprolidi.cz/cs/2000-128

Žantovský, M. (2014). Havel [Havel]. Praha: Argo.

\section{SUMMARY}

The goal of the text is to summarise and analyse commemorative strategies and trends that were used in case of the Czechoslovak and Czech president Václav Havel (1936-2011; 1989-2003, in office) and that were especially expressed through proper names, mostly street names. The research is primarily based on selected archival sources and opinion journalism of the day. The research issue is presented against the broad background of place names commemorating Czechoslovak and Czech presidents over the course of the 20th century. 